\section{COMPUTATIONAL SELF-EFFICACY AND INFORMATION SKILLS IN POSTGRADUATE STUDENTS IN ADMINISTRATION AT THE TIMES OF COVID-19}

\begin{abstract}
The objective of the research was to analyze the levels of computational self-efficacy and information skills in postgraduate students in administration at the time of COVID-19 with the aim of determining their relationship in academic performance. The type of study was a quantitative investigation with a correlational scope. The students were the graduate students in administration. The instruments used were two specific questionnaires with a Likert scale of five points each. The main results indicate that, during confinement, students had a frequency of using the laptop for three or more hours with a fixed connection. The level of their computational self-efficacy had an average of 4.55 , which is interpreted as a high level where women were valued to a greater extent; while the level of information skills was 4.00 on average, which implies that, almost always, the participants carry out actions aimed at fulfilling the need for information they need to continue their distance educational process during the confinement, regularly using search, use and organization strategies, as well as the evaluation of information sources.
\end{abstract}

\section{KEYWORDS}

\section{Computational self-efficacy, information skills, students, postgraduate courses in administration,} confinement

\section{HOW TO CITE}

Cardoso Espinosa E. O., Cortés Ruiz J. A., Cerecedo Mercado M. T. (2021) 'Computational Self-Efficacy and Information Skills in Postgraduate Students in Administration at the Times of Covid-19', Journal on Efficiency and Responsibility in Education and Science, vol. 14, no. 2, pp. 118-129. http://dx.doi.org/10.7160/eriesj.2021.140205
Edgar Oliver Cardoso Espinosa Jésica Alhelí Cortés Ruiz

María Trinidad Cerecedo Mercado

Instituto Politécnico Nacional

- Escuela Superior de Comercio

y Administración- Unidad Santo

Tomás, México

eoce@hotmail.com

\section{Article history}

Received

October 22, 2020

Received in revised form

February 7, 2021

Accepted

June 7, 2021

Available on-line

June 30, 2021

\title{
Highlights
}

- The postgraduate students in administration are familiar with the strategies for searching, using, organizing and evaluating computer resources which allow the generation of useful knowledge.

- The postgraduate students in administration have a high computational self-efficacy that has allowed them to continue with their academic training during confinement.

- The academic training of postgraduate degrees in administration in the future will be taught through the hybrid model that will allow students an organization and logistics on their time, rhythm and learning itinerary.

\section{INTRODUCTION}

The World Health Organization established in March 2020 the health emergency situation generated by the COVID-19 international pandemic, which directly impacted the educational systems of all countries, affecting the student body, homes, secretariats, educational centers, teachers and managers. Based on the above, the closure of educational centers was implemented as an extraordinary measure to contain the progression of the pandemic, so that $87 \%$ of students worldwide were no longer receiving their face-to-face classes (UNESCO, 2020). The distance education strategy was implemented, characterized by the use of digital content, platforms, and learning management systems. The purpose was to maintain the interaction between schools and students, so in the short term it is relevant to investigate the effect that it will have on the academic training of students by replacing face-to-face with virtual education (OECD, 2020; OEI, 2020). The confinement generated a rapid transition of the students 
to adapt and continue with their academic training, which has modified their personal and work activities to be carried out, where the factor of connectivity in the homes has been included, which affects the availability and time of use in front of a computer (Wang et al., 2020). Similarly, UNESCO (2020) establishes that the behavior of graduate level students in times of COVID-19 has had the openness, willingness and availability to integrate into distance education, which demands a greater degree of responsibility and commitment to academic training. However, it is important to note that they have also faced various personal and family situations and that when they found themselves working from home, they had to face and solve these challenges caused by the pandemic.

In this sense, the school as a physical place for students to acquire the skills to develop, changed drastically as it became a virtual environment where it no longer only focuses on promoting the expected learning, but also involves the emotional component that generates a motivation to continue with the academic training by the student body. Thus, the reorientation of the objectives and goals is essential for successful achievement during confinement to continue the educational service by the teaching staff (Y1ldıl1, 2019). To achieve this, in the situation caused by the presence of COVID-19, schools and teachers have incorporated technological resources, access and use of databases, and the adjustment of calendars to the postgraduate level to give continuity to the academic process (Martin and Furiv, 2020).

Similarly, the Banco Interamericano de Desarrollo (BID, 2020) considers that a relevant factor during confinement is the intrinsic characteristics that make students successful in distance education because their learning level is associated with their psychological traits and socio-emotional abilities. Thus, self-efficacy, motivation and skills in the management of technologies are the main elements associated with better results in educational performance (Wang et al., 2008). According to Safari, Davaribina and Khoshnevis (2020), selfefficacy is related to the belief of being successful in solving situations. In addition, it implies a positive state of mind to face the challenges generated. It also provides the security of being in control of emergencies, thereby reducing the degree of stress and depression.

Particularly in Mexico during March 2020, urgent measures were implemented for higher education institutions (HEIs) in order to give continuity to the delivery of programs through non-school options to successfully conclude the school period (ANUIES, 2020). Based on the above, the Instituto Politécnico Nacional (IPN, 2020) implemented the Virtual Plan for Academic Continuity organized by a set of technologies, resources, and tutorials. Its purpose was to pursue academic training in a collaborative online learning environment. Academic activities for the graduate level were carried out through virtual classrooms (Google Classroom); workspaces and collaboration (Microsoft Teams) and classes by videoconference (Zoom). The implementation of the Virtual Plan generated various ways of academic work and changes in the functions of its main educational actors: students and teachers, so it is relevant to carry out research on the abilities, skills and attitudes that have been evidenced during the emergency generated by COVID-19 and its impact on the culmination of the academic training of students.

Consequently, the main objective of the study is to analyze the levels of computational self-efficacy and information skills in postgraduate students in administration in times of COVID-19 in order to determine their relationship with academic performance.

\section{Previous literature}

The current socioeconomic approach considers knowledge and information and communication technologies (ICT) as structuring principles of changes in the different sectors and productive processes of a country. In the same way, the 21 st century society is characterized by a growing use of technological means, by the digitization of data and by the handling of a large amount of information, which has generated the emergence of new demands in the training of individuals who need to develop skills that allow them to access information, select it and disseminate it from any means both nationally and internationally. On the other hand, the success of organizations is measured by the development of capacities in productivity, innovation and creation of strategic value, which are achieved to the extent that human capital has the training to create, organize, share, apply and communicate knowledge (Jerónimo and Juárez, 2018; Bailey et al., 2017). Therefore, information and knowledge are the key elements for the operation and improvement of the quality of higher education because they enable the management of content, quantity, timeliness, relevance, acquisition and communication among its members (Lai and Wei, 2013).

Hence, higher education, where the postgraduate program is located, requires to consolidate its important role in the generation of human talent with fundamental capacities for the creation, storage and dissemination of knowledge, as well as the management of information, technology and digitization of the processes carried out in organizations (Begoña, 2015). In addition, in the context originated by COVID-19 which has forced the educational systems of the countries to establish distance education, it is relevant to investigate the knowledge, skills and attitudes of students both for the use of technological tools and for the management, analysis and uses of the information to determine if they are able to continue with their academic training. Therefore, computational selfefficacy and information skills are oriented towards literacy in technological tools (knowledge and use of hardware, software and multimedia programs); resource literacy (methods of access to informational resources); a research literacy (tools for academic work) and a literacy for publication (ability to disseminate and publish), which are used during academic training at the postgraduate level (López-Yepes, 2019).

From the contribution of the social cognitive theory of Bandura (2006), self-efficacy is defined as the assessment of one's own abilities to successfully perform a series of tasks. Therefore, self-efficacy is focused on beliefs about the capabilities of an individual that allow him to successfully achieve a series of activities; in this sense, people with a higher level of self-efficacy have a greater scope in their personal goals, which generates better mental health (Safari, Davaribina and Khoshnevis, 
2020). On the other hand, computational self-efficacy according to Compeau and Higgins (1995) and Marakas, Yi and Johnson (1998), is defined as the judgments of a person to use a computer, so it refers to the acquired capacities that are available to face the activities to be carried out in the future. This construct has been considered as a strategic capacity for the management and solution of various situations both at a personal and work level of a person (Kukul and Karatas, 2019). A person with high computational self-efficacy competently employs a variety of computer tools and systems based on the use of hardware and software.

The importance of investigating computational self-efficacy is to identify the strengths and weaknesses perceived in the students because if they consider the activities to be carried out as difficult, it is very likely that they will give up continuing with their academic path (Dumbauld et al., 2014). This term includes two relevant factors: efficiency in the performance as a person and effectiveness in achieving objectives (Safari, Davaribina and Khoshnevis, 2020). On the other hand, in the investigations of Bates and Khasawneh (2007) and Pellas and Kazanidis (2014), they determined a regular level of computational self-efficacy in the student body and concluded that it is a predictor of academic performance. In addition, it promotes commitment, responsibility, collaborative work and student satisfaction when using digital tools. In the studies by both Miura (1987) and Durndell, Haag and Laithwaite (2000), they found that males obtained higher scores in computational self-efficacy and concluded that it is a priority factor for the use or not of the computer. Subsequently, in the investigation of Durndell and Haag (2002) they found as results the existence of a significant correlation between computational self-efficacy, low computational anxiety, high positive attitude towards the Internet, as well as a longer time to use the Internet.

Meanwhile, García, Hernández and Peinado (2009) found that the computational self-efficacy of the student body presents a high average. Peinado de Briceño and Ramírez (2010b) identified a high level associated with a higher score in academic performance. Peinado de Briceño and Olmedo Casas (2013) in their study determined that the place of use, training and frequency of use of the computer have significant effects on computational self-efficacy. Specifically, they found that those students who use the computer on a daily basis perceive themselves with greater computational self-efficacy; those students who use the computer at home, have a higher computational self-efficacy and, the male gender are evaluated with a higher self-efficacy compared to the female. In the study by Krejčová, Chýlová and Michálek (2019), they found statistically significant gender differences in the category of perceived education, where females perceived themselves as having a higher level of selfefficacy and recommend investigating the relationship between computational self-efficacy with the educational trajectory of students. On the other hand, Yildizlı (2019) establishes the importance of including the management of self-efficacy in the educational environment as study variables, as well as the influence of teachers in the construction of student self-efficacy. On the other hand, a person is competent in information skills if he/she accesses and searches for information, efficiently uses it, and critically evaluates the diversity of sources and their relevance, which allows an effective organization to achieve the activity (Allison, 2015; Sánchez Díaz, 2012). Solís Valdespino (2013) determines that the information skills are to identify the structure of knowledge and information; recognize the need to use the information; formulate strategies for the search and retrieval of information; analyze and evaluate the information; organize, synthesize and use the information for the presentation of the results based on intellectual property and copyright. Its importance at the postgraduate level is to identify the key information from the research to organize it properly, selecting the correct and reliable sources based on its relevance and quality, which is why information skills are a relevant element in the educational training of students (Bruce, 2003; García and Díaz, 2007). Therefore, information skills are a strategic factor to increase the effectiveness of the teaching-learning process (Marzal Martínez et al., 2011).

The findings of previous research constitute the empirical foundation that corroborates that computational self-efficacy and information skills are relevant topics to be studied at the postgraduate level because students during their academic training use digital tools as the main means for searching, analyzing, organizing and synthesizing the information they consult in various sources. Based on the above, the importance of the study is to analyze the relationship between computational self-efficacy and information skills, which according to the previous literature are strategic factors that influence the academic performance of students. Specifically, the relevance of the research for postgraduate degrees in administration is to provide useful information on these two variables due to the fact that, before the appearance of COVID-19, they were taught in the face-to-face modality which characteristics of both teaching and learning are different from a distance modality. Therefore, the obtained results will be useful for the formulation of academic training strategies for a hybrid model that will be implemented once the confinement for these postgraduate programs is concluded.

During the COVID-19 pandemic, when the confinement was decreed and the remote modality was implemented, the use of technological tools became the priority element to continue with academic training, which implies the use of both computational self-efficacy as well as information skills. Thus, it was formulated: There is a direct and significant association between computational self-efficacy and information skills in the academic performance of postgraduate students in administration in times of COVID-19.

\section{MATERIALS AND METHODS Type of research}

Based on Hernández and Mendoza (2018), the type of study was a quantitative research with a correlational scope because it focused on determining the levels of both computational selfefficacy and information skills in the academic performance of postgraduate students in administration during confinement. The three research variables were computational self-efficacy and information skills, the information of which was collected from the application of two instruments; while the third variable was the academic performance obtained from the final average of each participant in the first semester of 2020. 


\section{Participants}

The population was made up of students who were studying a graduate degree in administration taught at the Instituto Politécnico Nacional (IPN) during the first semester of 2020, which was when the health emergency due to COVID-19 was announced, giving a total of 130 participants distributed in four programs: Master of Science in Business Administration (P1);
Master in Sustainable Business Administration (P2); Master of Administration in Public Policies (P3) and Doctorate in Administrative Sciences (P4). Based on Münch and Ángeles (2007), the sampling was carried out with $95 \%$ reliability with a $p=0.5$ and $q=0.5$, as well as an error of $5 \%$, for which a sample size of 92 subjects was obtained as shown in Table 1.

\begin{tabular}{c|c|c|c|c|c|c|c}
\multirow{2}{*}{$\begin{array}{c}\text { Educational } \\
\text { program }\end{array}$} & Age (years) & \multicolumn{3}{|c|}{ Gender } & \multicolumn{4}{c}{ Semester } \\
\cline { 2 - 9 } & Mean & Female & Male & I & II & III & IV \\
\hline P1 & 25.3 & 17 & 14 & 12 & 10 & 8 & 5 \\
\hline P2 & 26.2 & 13 & 12 & 9 & 9 & 7 & 2 \\
\hline P3 & 25.7 & 10 & 9 & 8 & 7 & 5 & 1 \\
\hline P4 & 32.4 & 9 & 8 & 3 & 2 & 3 & 1 \\
\hline Total & 27.4 & 49 & 43 & 32 & 28 & 23 & 9 \\
\hline
\end{tabular}

Table 1: Characteristics of the participants

From Table 1, the main characteristics of the sample were for age, a mean of 27.4 years was found; the distribution by gender was $53 \%$ in women and $47 \%$ in men. While for the semester, it was found that $35 \%$ study the first, $30 \%$ the second, $25 \%$ the third and the remaining $10 \%$, the fourth. Regarding the program of study, it was identified that $35 \%$ correspond to $\mathrm{P} 1$; $32 \%$ to $\mathrm{P} 2 ; 23 \%$ to $\mathrm{P} 3$ and the remaining $10 \%$ to $\mathrm{P} 4$.

\section{Instruments}

To carry out the research, two instruments were used to measure computational self-efficacy and information skills. The first was to determine computational self-efficacy, which was designed and validated by Peinado de Briceño and Ramírez (2010a), and has a total explained variance of $80.10 \%$; each of the items that make it up have a load greater than 0.40 and their reliability based on Cronbach's alpha coefficient is 0.895 , so their internal consistency is good. This instrument uses a five-point Likert-type scale ranging from totally disagree (1), disagree (2), neither disagree nor agree (3), agree (4) and totally agree (5) where it is composed of three dimensions: basic skills; advanced skills and internet skills.

Meanwhile, the second instrument was a questionnaire to study information skills, which was developed and validated by Girarte Guillén and del Valle López (2020). Its main characteristics are: sampling adequacy and Barlett's sphericity test $(K M O=0.906, p<0.001)$ for which it presents a good adaptation to the factorial model. The total variance explained is $67.601 \%$ with the fulfillment of the existence of communality of at least 0.504 . The reliability obtained by Cronbach's alpha coefficient is 0.958 ; therefore, it has a high internal consistency. This instrument also uses a five-point Likert-type scale ranging from never (1), almost never (2), occasionally (3), almost always (4) and always (5) where the dimensions are information needs; search and recovery; use of information; organization of information and evaluation of sources.

The relevance for using the two instruments was due to the fact that it was validated with participants at the postgraduate level both in its exploratory and confirmatory analysis, in addition to meeting the criteria of relevance and timeliness, coupled with the fact that the authors recommended its application to validate its use in other contexts (Peinado de Briceño and Ramírez, 2010a; Girarte Guillén and del Valle López, 2020). For the content validity of the instruments, the expert judgment technique was used; therefore, five researchers with a high degree of knowledge about educational research and distance educational environments with a trajectory of at least 10 years were selected. The experts analyzed them in the aspects of clarity, congruence and bias of the items to later carry out the necessary modifications. For the reliability of the instruments, it was carried out using Cronbach's alpha coefficient.

The internal consistency of the first instrument by means of Cronbach's alpha coefficient was 0.813 , which is why it is interpreted as good. The construct validity through the principal component analysis based on the KMO test was 0.945 and the Bartlett test of sphericity was statistically significant $\left(\chi^{2}=953.58, p<0.001\right)$, which indicates the existence of a good adequacy of the information obtained for a factorial model. The exploratory factor analysis was carried out, in which the existence of three factors that explained $79.12 \%$ of the total variance was found, which represents a valid multidimensional measure. For the second instrument, Cronbach's alpha coefficient was 0.876 ; the construct validity through the principal component analysis based on the $K M O$ test was 0.953 and the Barlett's test of sphericity was statistically significant $\left(\chi^{2}=1134.24, p<0.001\right)$ indicating a good fit for a factorial model. The exploratory factor analysis indicated the existence of five factors that explain $83.34 \%$ of the total variance (Morales, 2011).

Regarding the application of the two instruments, it was carried out through email, in which the objective of the investigation with the guarantee of confidentiality was indicated to each participant.

\section{Data Analysis}

Once the information was collected, the SPSS version 25 program was used to organize and analyze the data obtained from the participants through the use of descriptive and inferential statistics (Pérez, 2004). Thus, it was necessary to verify the normality or not of the distribution of the study data using the Kolmogorov-Smirnov $(K-S)$ statistical test. In 
the same way, parametric tests such as Pearson's $r$ correlation coefficient, as well as two-way Student's $t$ test and the oneway $A N O V A$ test were used to determine the existence or not of significant differences and to find the level of association between the study variables with a level of significance of $p<0.05$.

\section{RESULTS}

With regard to the situations faced by the postgraduate students in administration during the health emergency, they are organized in Table 2. The main situations were of a logistical nature (organization and management of time, class, work and family schedules; physical space for working remotely); of a socio-affective type (circumstances related to affective and health aspects) in which the students acknowledged experiencing feelings of sadness, frustration, anxiety, tiredness and demotivation; educational (remote participation, carrying out activities and sending assignments online) and technological (internet access and availability of computer equipment). In the same way, the findings obtained in Table 2 are relevant because they indicate the diversity of situations that postgraduate students in administration have faced during the COVID-19 pandemic in which, before, the provision of academic training was face-to-face, so they did not face this type of events on a recurring basis. Thus, the issues which stand out are: The management of time to face, organize and comply with the simultaneous attention both for their postgraduate academic training as well as for their work and personal life. The manifestation of the socio-emotional component due to the fact that it is a new experience which the students had not lived and that an abrupt change from the faceto-face modality to a virtual one was not in their training plans. In addition, the technological element in which it was found that some students lack their own computer equipment since they use the equipment from their work center, so they were attended through other devices such as tablets or cell phones.

\begin{tabular}{l|ll}
\multicolumn{1}{c|}{$\begin{array}{c}\text { Item } \\
\text { During the confinement I had to }\end{array}$} & Mean & Standard deviation \\
\hline Organize my time to fulfill my training & 4.89 & 0.21 \\
\hline Establish a physical space to fulfill the academic and work & 4.78 & 0.57 \\
\hline Address family situations & 4.26 & 0.91 \\
\hline Comply with work activities & 4.11 & 0.98 \\
\hline Lose my source of employment & 4.51 & 0.74 \\
\hline Experience frustration & 4.67 & 0.64 \\
\hline Experience sadness & 4.53 & 0.77 \\
\hline Live with anxiety and uncertainty & 4.81 & \\
\hline Recognize fatigue for completing academic and work duties & 4.32 & \\
\hline Feel disinterested and unmotivated & 4.13 & \\
\hline Participate remotely but it has been difficult for me & 3.79 & 0.32 \\
\hline Do the learning activities but it has been difficult for me & 0.93 \\
\hline Submit tasks but it has been difficult for me & 4.08 & 1.09 \\
\hline Solve problems with internet access & 3.68 & 1.02 \\
\hline I don't have a computer equipment & 3.12 & 1.15 \\
\hline
\end{tabular}

Table 2: Situations faced by the participants

On the other hand, Table 3 shows the findings of the computational self-efficacy of the postgraduate students in administration.

Based on Table 3, a general mean of 4.75 points is found for the basic skills dimension, which is interpreted as a high assessment from the perception of the postgraduate students in administration and refers to the fact that they agree to use these skills when they use a computer. In particular, those related to opening and saving a file (4.91), working on a personal computer (4.87), the correct handling of storage devices (4.85), accessing and exiting a computer program (4.84) are identified with the highest averages, as well as using the computer to write a dossier or report (4.82).

Regarding the dimension of advanced skills, a global average of 4.23 points was determined, which is interpreted as a high assessment in the level of development of the students, which implies that the participants agree to use these skills when they use a computer. In the same order, skills with higher averages stand out, such as using the computer to organize information (4.95), understanding terms related to software (4.83), adding and deleting information from a file (4.78), managing software installed in the computer (4.76) and the use of a program for data analysis (4.57).

For the third dimension called Internet skills, a general average of 4.66 points was obtained, which is interpreted as the participants having a high level of development that means a continuous mastery when they access, visit and consult the Internet to carry out the activities related to their academic training at the postgraduate level. In the same way, of the eight skills that make up this dimension, seven have an average score greater than 4.50. Only the handling and interaction through a forum or chat is valued with a 4.24. Finally, the global mean for the variable of computational self-efficacy is 4.55 , which is interpreted as a consolidated level of development in the postgraduate administration students. That is, the participants of the study agree that basic, advanced, and internet skills are important when using a computer. 


\begin{tabular}{|c|c|c|}
\hline $\begin{array}{l}\text { Item } \\
\text { During confinement }\end{array}$ & Mean & Standard deviation \\
\hline \multicolumn{3}{|l|}{ Mastery experiences } \\
\hline I know how to work on a personal computer & 4.87 & 0.56 \\
\hline I know how to handle the software installed on the computer & 4.76 & 0.69 \\
\hline I know how to access and exit a computer program & 4.84 & 0.18 \\
\hline I handle storage devices correctly & 4.85 & 0.17 \\
\hline I can add and delete information from a file & 4.78 & 0.18 \\
\hline I send an email & 4.93 & 0.04 \\
\hline I use the computer to organize information & 4.95 & 0.03 \\
\hline I know how to attach files to an email & 4.96 & 0.02 \\
\hline I can read and reply to an email & 4.97 & 0.03 \\
\hline \multicolumn{3}{|l|}{ Vicarious experience } \\
\hline I know how to open and save a file to work & 4.91 & 0.06 \\
\hline I understand the terms related to hardware & 3.84 & 1.14 \\
\hline I understand the terms related to the software & 4.83 & 0.21 \\
\hline I can use a specific computer program to analyze numerical data & 4.57 & 0.84 \\
\hline I know how to transfer from one storage device to another & 4.21 & 0.96 \\
\hline I use the computer to write a dossier or report & 4.82 & 0.11 \\
\hline I know how to locate information on the Internet & 4.55 & 0.91 \\
\hline I use digital tools for my academic training & 4.56 & 0.94 \\
\hline \multicolumn{3}{|l|}{ Social persuasion } \\
\hline I can carry out teamwork with support on the Internet & 4.55 & 0.83 \\
\hline I can use a variety of computer programs & 4.14 & 0.94 \\
\hline I know how to store information found on the Internet & 4.52 & 0.86 \\
\hline I know the menu of every computer program & 4.64 & 0.92 \\
\hline I know how to handle and interact through a forum or chat & 4.24 & 0.96 \\
\hline I know the functions of the computer hardware & 4.11 & 0.98 \\
\hline I organize and manage files simultaneously & 4.36 & 0.91 \\
\hline I have skills to learn about a specific program & 4.21 & 0.86 \\
\hline \multicolumn{3}{|l|}{ Affective states } \\
\hline I read user guides when I need help & 3.85 & 1.12 \\
\hline I understand the three phases of information processing: input, process and output & 4.07 & 1.09 \\
\hline I store programs correctly & 4.34 & 0.92 \\
\hline I explain why a program will or will not run on the computer & 3.77 & 1.04 \\
\hline I solve computer technical problems & 3.73 & 1.13 \\
\hline I seek help when I have technical problems & 4.04 & 1.03 \\
\hline I delete files when they are no longer needed or storage runs out & 3.73 & 1.16 \\
\hline
\end{tabular}

Table 3: Descriptive statistics of computational self-efficacy

In relation to the level of development of information skills in postgraduate students in administration, they are shown in Table 4.

Based on Table 4, for the first dimension of information skills referring to the need for information, a general mean of 4.25 points was found, which means that almost always postgraduate participants recognize the relevance of requiring information for their academic training during confinement. Thus, the skills with the highest average are to summarize and outline the information (4.72), the consultation and use of electronic sources (4.68), differentiate between the types of information (4.43), clarity of the objective when a search is carried out (4.32), identify the main ideas of the documents (4.28), the use of various sources of information in research (4.15), as well as recognize the information required (4.14). For the second dimension of information skills on search and recovery, a general average of 3.92 points was obtained, which is interpreted as the fact that participants occasionally carry out activities related to the location and recovery of lost files during their remote academic training. Among those that stand out for a greater assessment by the student body is to determine if the information contained in a resource is updated (4.63), as well as to know and use the information banks and digital repositories (4.21).

Regarding the third dimension about the use of information, a global average of 3.80 points was found, the finding of which is interpreted as the fact that occasionally, during confinement, postgraduate students in administration use the information resource for management, analysis and interpretation. So, it is deduced that they are in a process of academic development according to the semester in which they are. In this sense, the competence with the highest value was making academic presentations using computer programs (4.87). 


\begin{tabular}{|c|c|c|}
\hline $\begin{array}{l}\text { Item } \\
\text { During confinement }\end{array}$ & Mean & Standard deviation \\
\hline I am able to identify the information I need & 4.14 & 0.87 \\
\hline I am clear about the objective when I perform a search & 4.32 & 0.83 \\
\hline I can consult and use electronic sources of information & 4.68 & 0.81 \\
\hline I know how to discriminate between types of information sources & 4.43 & 0.92 \\
\hline I can identify the main ideas of documents & 4.28 & 0.89 \\
\hline I can evaluate the quality of information resources & 3.75 & 1.03 \\
\hline I know how to use various sources of information in the research process & 4.15 & 0.80 \\
\hline I can define the depth level of the content I want to get & 3.79 & 1.27 \\
\hline I can summarize and outline the information & 4.72 & 0.86 \\
\hline I know and apply the legislation on the use of information and intellectual property & 3.47 & 0.94 \\
\hline $\begin{array}{l}\text { I know the typology of the sources of scientific information (research articles, discussion } \\
\text { articles, thesis and conference proceedings) }\end{array}$ & 3.92 & 0.99 \\
\hline I know how to access and use information banks and digital repositories & 4.21 & 1.13 \\
\hline I know how to use reference managers (Mendeley, EndNote, RefWorks) & 3.53 & 1.34 \\
\hline I am able to determine if the information contained in a resource is up to date & 4.63 & 1.14 \\
\hline I know the terminology of the knowledge area in which I search for information & 3.88 & 1.29 \\
\hline I know the most relevant authors or institutions in the field of the subject I am researching & 3.78 & 1.42 \\
\hline $\begin{array}{l}\text { I know how to properly disseminate information on the Internet (web, blogs, congresses } \\
\text { and magazine ads) }\end{array}$ & 3.21 & 1.48 \\
\hline I can make academic presentations using computer programs such as Power Point & 4.87 & 0.25 \\
\hline I know how to publicly communicate the results and conclusions & 3.39 & 1.45 \\
\hline I can write a document (academic report or research report) & 3.94 & 1.02 \\
\hline I handle the different citation styles & 3.84 & 0.95 \\
\hline I can write a bibliography according to a citation style & 3.54 & 0.93 \\
\hline I handle statistical programs in the research process & 3.75 & 1.15 \\
\hline I can interpret research results (tables and graphs) & 3.24 & 1.53 \\
\hline I can handle different strategies in the use of information & 4.23 & 1.24 \\
\hline I use the information bearing in mind the respect for copyright & 3.64 & 0.95 \\
\hline I am able to recognize the structure of a text & 4.82 & 0.88 \\
\hline I know the ethical code of my academic and professional field & 3.91 & 1.02 \\
\hline
\end{tabular}

Table 4: Descriptive statistics of information skills

Meanwhile, for the fourth dimension focused on the organization, a general average of 3.74 points was found, which is interpreted in that occasionally the postgraduate participants carry out a planning of the activities to be carried out to obtain and structure the information they locate. Hence, there is only one competence with the highest average, which is the management of different strategies for the use of information (4.23).

While for the fifth dimension on the evaluation of sources, a general average of 4.12 was determined, which means that the postgraduate students in administration almost always carry out their academic training at a distance. There is only one competence which is to recognize the structure of a text (4.82). Finally, the information skills on their global scale obtained
4.00, a fact which is interpreted in that almost always the participants during confinement take actions oriented towards meeting the need for information they require to continue with their distance educational process using strategies of search, use, organization and evaluation of information sources.

Subsequently, to determine if the hypothesis of the study is verified, the $K-S$ test was used for the two research variables: For computational self-efficacy, the statistic test was 0.715 with a $p=0.384$, which is why it is concluded that its distribution is normal. For information skills, the statistic test was 0.856 with a $p=0.211$, so the fulfillment of normality in its distribution is concluded. Therefore, Pearson's $r$ correlation, two-sided Student's $t$ and one-way ANOVA are used as the parametric tests.

\begin{tabular}{lcccc}
\multicolumn{1}{c}{ Variable } & Computational self-efficacy & Information skills & Academic performance \\
\hline Computational self-efficacy & 1.000 & $0.548^{*}$ & $0.836^{*}$ \\
\hline Information skills & & 1.000 & $0.764^{*}$ \\
\hline Academic performance & & & 1.000 \\
\hline
\end{tabular}

$$
* p<0.05
$$

Table 5: Correlation between computational self-efficacy, information skills and performance 
Table 5 shows the correlations between the study variables in which the findings were found as follows: There are direct and significant associations between computational self-efficacy and information skills of 0.548 , between computational self-efficacy and academic performance of 0.836 , as well as between information skills and academic performance with a 0.764. Based on these results, the research hypothesis regarding the existence of a direct and significant association between computational self-efficacy and information skills with the academic performance of postgraduate students in administration in times of COVID-19 is verified.

\begin{tabular}{|c|c|c|c|c|c|c|}
\hline Gender & $\begin{array}{c}\text { Computational self-efficacy } \\
\text { Mean }\end{array}$ & $t$ & $p$ & $\begin{array}{c}\text { Information skills } \\
\text { Mean }\end{array}$ & $t$ & $p$ \\
\hline Female & 4.86 & \multirow{2}{*}{4.214} & \multirow{2}{*}{$<0.001$} & 4.47 & \multirow{2}{*}{0.500} & \multirow{2}{*}{0.214} \\
\hline Male & 4.24 & & & 4.36 & & \\
\hline
\end{tabular}

\section{Table 6: $\boldsymbol{t}$ test for gender}

From Table 6, the existence of a significant difference was found for the variable of computational self-efficacy with respect to gender $(t=4.214, p<0.001)$, but the test of homogeneity of variances is not statistically significant $(p=0.416)$. This finding implies that females perceive themselves with a higher level of computational self-efficacy with respect to males.
On the contrary, for the information skills variable, there is no significant difference in gender $(t=0.500, p=0.214)$ and the test of homogeneity of variances is also not statistically significant $(p=0.153)$. This result implies that both males and females are valued with the same level of mastery in information skills.

\begin{tabular}{|c|c|c|c|c|c|c|}
\hline \multirow{2}{*}{ Semester } & Computational self-efficacy & \multirow{2}{*}{ ANOVA $(F)$} & \multirow{2}{*}{$p$} & Information skills & \multirow{2}{*}{ ANOVA $(F)$} & \multirow{2}{*}{$p$} \\
\hline & Mean & & & Mean & & \\
\hline First & 3.97 & \multirow{4}{*}{5.624} & \multirow{4}{*}{$<0.001$} & 3.37 & \multirow{4}{*}{7.638} & \multirow{4}{*}{$<0.001$} \\
\hline Second & 4.60 & & & 3.55 & & \\
\hline Third & 4.78 & & & 4.39 & & \\
\hline Fourth & 4.85 & & & 4.69 & & \\
\hline
\end{tabular}

Table 7: ANOVA test for the semester

Table 7 shows the results of the one-way ANOVA test for the study semester in which the study participants were enrolled. Significant differences were found for computational selfefficacy $(F=5.624, p<0.001)$ and the test of homogeneity of variances is not statistically significant $(p=0.345)$. For the information skills, significant differences were also found $(F=7.638, p<0.001)$ and the test of homogeneity of variances is not statistically significant $(p=0.423)$. Therefore, the previous results indicate the existence of statistically significant differences in the research participants in the postgraduate degrees in administration for the two variables of the study.

\begin{tabular}{|c|c|c|c|c|c|c|}
\hline Program & $\begin{array}{c}\text { Computational self-efficacy } \\
\text { Mean }\end{array}$ & ANOVA (F) & $p$ & $\begin{array}{c}\text { Information skills } \\
\text { Mean }\end{array}$ & ANOVA $(F)$ & $p$ \\
\hline P1 & 4.62 & \multirow{4}{*}{8.345} & \multirow{4}{*}{$<0.001$} & 3.79 & \multirow{4}{*}{4.254} & \multirow{4}{*}{0.002} \\
\hline $\mathrm{P} 2$ & 4.49 & & & 4.03 & & \\
\hline P3 & 4.23 & & & 3.95 & & \\
\hline P4 & 4.86 & & & 4.23 & & \\
\hline
\end{tabular}

Table 8: ANOVA test by educational program

Table 8 shows the results of the one-way ANOVA test by the educational program, where statistically significant differences were found for computational self-efficacy $(F=8.345, p<0.001)$ and the test of homogeneity of variances is not statistically significant $(p=0.526)$. Similarly, for the information skills, statistically significant differences were also determined $(F=4.254, p<0.001)$ and the test of homogeneity of variances is not statistically significant $(p=0.286)$. So, previous results indicate that both study variables have a different domain in each graduate degree in administration.

\section{DISCUSSION}

The health emergency due to the coronavirus generated as a fundamental requirement the integration of technological tools to maintain the educational service in order not to affect the academic training of the student body, which is why it coincides with Martin and Furiv (2020) because the student body has a technological device, a type of the Internet connection, as well as allocates a time of at least three hours to carry out academic activities at the graduate level. Thus, the statement by UNESCO (2020) is confirmed in that the participants of this educational level show greater dedication, responsibility and commitment to their training, so that even during confinement they have attended both their work and academic activities. Therefore, this result indicates that postgraduate-level students in administration have sufficient conditions to continue their educational path at a distance, which is confirmed by the direct association with the academic performance obtained in times of COVID-19. In the same way, even after the confinement is concluded, it means that in the future students will be able 
to carry out learning activities based on the establishment of a hybrid model that will possibly be implemented in the education sector in the case of the graduate level in Mexico.

In this sense, the present research provides relevant information regarding what is established by both the OECD (2020) and the OEI (2020) regarding the relevance of carrying out studies aimed at determining the effect it has on the academic training of students when migrating from a face-to-face alternative to a virtual one in times of COVID-19. The study also coincides with Y1ldizlı (2019) in regard to conceiving the school no longer as the physical place where competences are acquired, but rather that the coronavirus turned the classroom into a virtual environment that implies both greater motivation and responsibility in the student body. For this reason, it was preponderant to determine both their information skills and their self-efficacy oriented towards computational management. This result makes it possible to determine that distance education has been successful at the postgraduate level, so it is relevant to include in the future, within the academic training of the student body, the performance of both synchronous and asynchronous activities mediated by the use of technological tools.

Also, the computational self-efficacy has been recognized as one of the fundamental factors for students to continue with their academic training in times of COVID-19, so a high level was determined for the postgraduate level, and based on Safari, Davaribina and Khoshnevis (2020). This observation implies that the participants have both the belief of being successful and a positive state of mind to face the challenges generated by the presence of the coronavirus. Thus, this finding implies that postgraduate-level students in administration recognize that the coronavirus pandemic has impacted on their personal, academic and work performance, which is why they possess the skills of self-knowledge and self-management that allowed them to reorganize their activities from the beginning of the lockdown. Also, it is relevant to recognize that students have a positive computational self-efficacy that has allowed them to continue with their educational training.

The findings of the study carried out with postgraduate students in administration confirm what was found by Pellas and Kazanidis (2014); Peinado de Briceño and Ramírez (2010b); Bates and Khasawneh (2007) in what refers to the fact that computational self-efficacy is associated with academic performance due to the fact that through the use of digital tools it enables teamwork, as well as the preparation and delivery of academic tasks. In the same way, it agrees with the result obtained by Durndell and Haag (2002) in the existence of a relationship between computational self-efficacy with the time spent on the Internet. The above results allow corroborating the relevance of continuously using technological tools in postgraduate academic training. Thus, its incorporation for the hybrid learning model that will be used in the future is strengthened as a main strategy.

On the contrary, a different finding was found to that established by Peinado de Briceño and Olmedo Casas; Durndell, Haag and Laithwaite (2000); Miura (1987) regarding the level of the computational self-efficacy for gender. These authors investigated that male students obtained a higher score in the computational self-efficacy, whereas the results in this article show the opposite. On the contrary, a different result than that of Krejčová, Chýlová and Michálek (2019) was identified with respect to the fact that females perceived themselves as having a higher level of self-efficacy. Additionally, another different result was the high level for this construct to that reported by Bates and Khasawneh (2007); Pellas and Kazanidis (2014). However, this result coincides with the level of computational self-efficacy by gender found by Peinado de Briceño and Ramírez (2010b) and García, Hernández and Peinado (2009). This result indicates the existence of different levels in computational self-efficacy by gender at the graduate level. So, it will be a main feature to consider in the future for postgraduate academic training.

Besides, what was previously found by Allison (2015), Sánchez Díaz (2012) and Bawden (2002) with regard to the fact that a student is able to recognize his/her information needs, knows how to locate, retrieve, evaluate, organize and use the information to achieve the activity that for this study was to conclude the semester by means of the distance education is confirmed, which is corroborated by the direct and significant association found with academic performance. Thus, this observation coincides with Marzal Martínez et al. (2011) in which information skills are a strategic factor to increase the effectiveness of learning. Also, Solís Valdespino (2013) agrees that postgraduate participants possess the information skills related to determining the nature of an information need; propose effective strategies to search and find information; retrieve information; analyze and evaluate information; integrate, synthesize and use information. However, the respect for intellectual property and copyright has not yet been developed in a consolidated manner. These findings determine the relevance of including information skills in postgraduate academic training, which are important capacities that students possess because during their educational journey they are required for the fulfillment of both learning activities and the preparation of their final degree project.

Therefore, the results of the investigation confirm what was stated by Wang et al. (2020) in regard to the fact that the situation caused by the coronavirus motivated the student body to quickly adapt to distance education to continue with their academic training and thus not be affected in their educational trajectory, which is corroborated by the existence of direct and significant associations of the two study variables with school performance. This finding means that postgraduate-level students possess the skills of adaptability and resilience, which were manifested in the face of the COVID-19 pandemic. Also, the established by Safari, Davaribina and Khoshnevis (2020) is confirmed in that having a high computational self-efficacy allows the participants of the study to be efficient in their performance as postgraduate students, as well as effective to continue their distance academic training during confinement. This result implies the existence of self-regulation and self-knowledge skills in postgraduate level students in administration, which is why they are important capacities that will allow them to face similar situations in the future.

In the same way, the results of the study provide relevant information about the various situations caused by the 
coronavirus pandemic in the graduate level participants. The logistical, socio-emotional, educational and technological types stand out. This finding implies the existence of self-control, self-esteem and decision-making skills in students, which are important because they influence academic performance. Finally, the results of the study confirm what is established by Jerónimo and Juárez (2018) and Bailey et al. (2017) in terms of the human capital possessing the competencies to access, select and organize information to create and communicate knowledge, so the postgraduate level is developing it in the student body. Thus, this educational training will have an impact on the organizations in which they work because they will benefit their productivity, innovation and creation of strategic value.

\section{CONCLUSION}

Based on the panorama originated by COVID-19 in which distance education was implemented to continue the academic training of the student body, it was important to carry out a research on two important success factors that influence both academic performance and educational path and which are computational self-efficacy and information skills. Consequently, the general objective of the study was achieved by providing relevant findings on its levels and characteristics in the students of the graduate degrees in administration in terms of gender, semester of study and educational program where the average of the two study variables were high. Also, the study hypothesis was verified as there was a direct and significant association between computational self-efficacy and information skills with academic performance. In the same way, the research provides relevant information on the level of mastery of two variables in the postgraduate programs in administration before the appearance of COVID-19, which were taught in person. So, the findings will allow the design of strategies for academic training for the hybrid model (blended learning) that will be implemented once the confinement is completed. Therefore, the importance of the study is to anticipate that postgraduate students in administration, by managing a high domain in their computational self-efficacy and information skills, will be able to combine face-to-face work with virtual work for their academic training. Also, identifying the level of mastery of the participants of the postgraduate courses in administration in the two variables will allow them as students to have a greater organization and logistics regarding their time, rhythm and learning itinerary. Nevertheless, the main limitations of the research carried out are the size of the sample because it is focused on the students of the same educational institution and one area of knowledge, as well as the instruments used were the questionnaires to obtain the information. In this sense, it is recommended for future studies to broaden the participants to include students of postgraduate studies from different institutions, as well as to include different areas of knowledge with the intention of comparing the levels of computational self-efficacy and information skills. This is due to the fact that these two terms maintain their relevance within the academic training at the postgraduate level because they allow the identification, selection, organization and evaluation of the information that enables the generation of useful knowledge that can be used in the student body's labor sector.

Furthermore, it is suggested to use the qualitative approach in order to collect the testimonies of the participants regarding their experience in the distance academic process in times of COVID-19. The foregoing with the intention of identifying the causes and consequences experienced by graduate level students to determine educational intervention strategies oriented towards their care during the pandemic and the post-pandemic period. In this sense, the academic training of the student body will continue in parallel with the socio-emotional component in order to successfully complete the educational path.

\section{ACKNOWLEDGMENT}

This article was supported by the Instituto Politécnico Nacional, México under the "Educational leadership for sustainable organizational development in the new normal (SIP20210598)".

\section{REFERENCES}

Allison, D. (2015) 'Measuring the academic impact of libraries', Portal: Libraries and the Academy, Vol. 15, No. 1, pp. 29-40. https://doi.org/10.1353/pla.2015.0001

ANUIES (2020) Acuerdo Nacional por la Unidad en la Educación Superior frente a la emergencia sanitaria provocada por el covid-19, [National Agreement for the Unit in Higher Education in the face of the health emergency caused by the covid-19], Asociación Nacional de Universidades e Instituciones de Educación Superior, [Online], Available: http://www.anuies.mx/ media/docs/avisos/pdf/200424155500Acuerdo+Nacional+frente + al+COVID-19.pdf [7 Jun 2020].

Bailey, J. Rodríguez, M., Flores, M. and González, P. (2017) 'Contradicciones y propuestas para la educación en la sociedad del conocimiento', [Contradictions and proposals for education in the knowledge society], Sophia, Vol. 13, No. 2, pp. 30-39. https://doi.org/10.18634/sophiaj.13v.2i.571
BID (2020) Los sistemas educativos de América Latina y el Caribe ante COVID-19, [The education systems of Latin America and the Caribbean in the face of COVID-19], Banco Interamericano de Desarrollo [Online], Avaliable: https://publications.iadb.org/publications/spanish/document/ La-educacion-en-tiempos-del-coronavirus-Los-sistemaseducativos-de-America-Latina-y-el-Caribe-ante-COVID-19. pdf [3 Sep 2020].

Bandura, A. (2006) Guide for constructing self-efficacy scales, In Pajares, F. and Urdan, T. (eds.), Self-efficacy beliefs in adolescents (pp. 307-337), Greenwich, CT: Information Age.

Bates, R. and Khasawneh, S. (2007) 'Self-efficacy and college students' perceptions and use of online learning systems', Computers in Human Behavior, Vol. 23, No. 1, pp. 175-191. https://doi.org/10.1016/j.chb.2004.04.004 
Begoña, G. (2015) 'La caída de los muros del conocimiento en la sociedad digital y las pedagogías emergentes', [The fall of the walls of knowledge in the digital society and emerging pedagogies], Education in the Knowledge Society, Vol. 16, No. 1, pp. 58-68. https://doi.org/10.14201/eks20151615868

Bawden, D. (2002) 'Revisión de los conceptos de alfabetización informacional $\mathrm{y}$ alfabetización digital', [Review of the concepts of information literacy and digital literacy], Anales de Documentación, No. 5 pp. 361-408.

Bruce, C. S. (2003) 'Las siete caras de la alfabetización en información en la enseñanza superior', [The seven faces of information literacy in higher education], Anales de Documentación, No. 6, pp. 289-294.

Compeau, R. and Higgins, A. (1995) 'Computer self-efficacy: development of a measure and initial test', MIS Quart, Vol. 19, No. 192, pp. 189-211. https://doi.org/10.2307/249688

Dumbauld, J., Black, M., Depp, C. A., Daly, R. Curran, M. A., Winegarden, B. and Jeste, D. V. (2014) 'Association of Learning Styles with Research Self-Efficacy: Study of Short-Term Research Training Program for Medical Students', Clinical and Translational Science, Vol. 7, No. 6, pp. 489-492. https://doi. org/10.1111/cts.12197

Durndell, A. and Haag, Z. (2002) 'Computer self-efficacy, computer anxiety, attitudes towards the Internet and reported experience with the Internet, by gender, in an Eat European simple', Computers in Human Behavior, Vol. 18, No. 5, pp. 521-535. https://doi. org/10.1016/S0747-5632(02)00006-7

Durndell, A., Haag, Z. and Laithwaite, H. (2000) 'Computer selfefficacy and gender: a cross cultural study of Scotland and Romania', Personality and individual differences, Vol. 28, Vol. 6, pp. 1037-1044. https://doi.org/10.1016/S0191-8869(99)00155-5

García, F. and Díaz, A. (2007) Formación de usuarios y alfabetización informacional: dinámicas de trabajo en bibliotecas públicas, [User training and information literacy: work dynamics in public libraries], En Gómez, R. (Ed.), Acción pedagógica en organizaciones artísticas y culturales, Vitoria: Xabide.

García, H., Hernández, M. and Peinado, S. (2009) 'Respuesta psicofisiológicas y cognitivas ante situaciones estresantes en estudiantes de laUniversidad Simón Bolívar', [Psychophysiological and cognitive responses to stressful situations in students of the Simón Bolívar University], Revista de la Facultad de Medicina, Vol. 32, No. 2, pp. 107-112.

Girarte Guillén, J. L. and del Valle López, J. A. (2020) 'Validación de un instrumento sobre habilidades informativas', [Validation of an instrument on information skills], Apertura, Vol. 12, No. 1, pp. 152-162. http://dx.doi.org/10.32870/Ap.v12n1.1812

Hernández, R. and Mendoza, C. (2018) Metodología de la investigación: Las rutas cuantitativa, cualitativa y mixta, [Research methodology: The quantitative, qualitative and mixed routes], México: Mc Graw Hill.

IPN (2020) 'Plan virtual de continuidad académica', [Virtual academic continuity plan], Instituto Politécnico Nacional, [Online], Available: https://elementosdeaprendizaje.ipn.mx/ [15 May 2020].

Jerónimo, E. and Juárez, L. (2018) 'El índice de la economía del conocimiento: una propuesta para su cálculo a nivel municipal', [The knowledge economy index: a proposal for its calculation at the municipal level], Espacios, Vol. 39, No. 53, pp. 21-27.

Krejčová, K., Chýlová, H. and Michálek, P. (2019) 'A Role of Siblings in Perception of Academic Self-Efficacy and Social Support', Journal on Efficiency and Responsibility in Education and Science, Vol. 12, No. 4, pp. 126-134. https://doi.org/10.7160/ eriesj.2019.120403
Kukul, V. and Karatas, S. (2019) 'Computational Thinking SelfEfficacy Scale: Development, validity and reliability', Informatics in Education, Vol. 18, No. 1, pp. 151-164. https:// dx.doi.org/10.15388/infedu.2019.07

Lai, J. and Wei, D. (2013) 'Collaboration between teachers and librarians for information literacy curriculum: A case study of a Hong Kong Secondary School', Journal of Studies in Education, Vol. 3, No. 3, pp. 75-91. https://doi.org/10.5296/ jse.v3i3.3859

López-Yepes, J. (2019) 'El desarrollo de habilidades informativas y de creación de nuevo conocimiento: los conceptos de literacidad informativa (alfabetización informacional) y literacidad crítica', [The development of information skills and the creation of new knowledge: the concepts of information literacy (information literacy) and critical literacy], Ibersid, Vol. 13, No. 1, pp. 29-36.

Marakas, G. M., Yi, M. Y. and Johnson, R. D. (1998) 'The multilevel and multifaceted character of computer self-efficacy: toward a clarification of the construct and an integrative framework for research', Information Systems Research, Vol. 9, No. 2, pp. 126163. https://doi.org/10.1287/isre.9.2.126

Martin, M. and Furiv, U. (2020) COVID-19 shows the need to make learning more flexible. University World News. The Global Window on Higher Education, [online], Available: https://www. universityworldnews.com/post.php?story $=20200324115802272$ [4 Jul 2021].

Marzal Martínez, F. J., Solano Fernández, J. P., Vázquez, G., Muñoz, J. P. and Ros, J. (2011) 'Desarrollo y evaluación de la competencia de la gestión de la información en titulaciones técnicas: estudio de casos', [Development and assessment of the competence of information management in technical degrees: case study], Conference presented at the International Congress of Teaching Innovation at the Polytechnic University of Cartagena, Colombia, [Online], Available: http://hdl.handle. net/10317/2281 [8 Sep 2020].

Miura, I. (1987) 'The relationship of computer self-efficacy expectations to computer interest and course enrollment in college', Sex Roles, Vol. 16, No. 5, pp. 303-311. https://doi. org/10.1007/BF00289956

Morales, P. (2011) El análisis factorial en la construcción e interpretación de test, escalas y cuestionarios, [Factor analysis in the construction and interpretation of tests, scales and questionnaires], Madrid: Universidad Pontífica Comillas.

Münch, L. and Ángeles, E. (2007) Métodos y técnicas de investigación, [Methods and techniques of research], México: Trillas.

OEI (2020) Efectos de la crisis del coronavirus en la educación, [Effects of the coronavirus crisis on education], Organización de Estados Iberoamericanos para la Educación, la Ciencia y la Cultura [Online], Available: https://www.oei.es/Ciencia/Noticia/ oei-analiza-como-afectara-el-cierre-colegios-coronavirus [15 Jun 2020].

OECD (2020) A helping hand: Education responding to the coronavirus pandemic, Organisation for Economic Co-operation and Development [Online], Available: https://oecdedutoday. com/education-responding-coronavirus-pandemic/ [20 May 2020].

Peinado de Briceño, S. E. and Ramírez, J. J. (2010a) 'Adaptación de un instrumento para evaluar la autoeficacia computacional en estudiantes venezolanos', [Adaptation of an instrument to assess computational self-efficacy in Venezuelan students], Enseñanza e Investigación en Psicología, Vol. 15, No. 1, pp. 21-30. 
Peinado de Briceño, S. and Ramírez, J. J. (2010b) 'Efecto de los estilos de aprendizaje y la autoeficacia computacional sobre el desempeño en el foro electrónico', [Effect of learning styles and computational self-efficacy on performance in the electronic forum], Investigación y Postgrado, Vol. 25, No. 1, pp. 145-168.

Peinado de Briceño, S. and Olmedo Casas, K. (2013) 'La autoeficacia computacional, el entrenamiento, la frecuencia y el lugar de uso de computadoras en estudiantes universitarios venezolanos', [Computational self-efficacy, training, frequency and place of computer use in Venezuelan university students], Revista Electrónica de Investigación y Docencia (REID), Vol. 9, pp. 111-125.

Pellas, N. and Kazanidis I. (2014) 'The impact of computer self-efficacy, situational interest and academic self-concept in virtual communities of inquiry during the distance learning procedures through second life', World Wide Web, Vol. 17, pp. 695-722. https://doi.org/10.1007/ $\underline{\text { s11280-013-0266-9 }}$

Pérez, C. (2004) Técnicas de análisis multivariante de datos: aplicaciones con SPSS, [Multivariate data analysis techniques: applications with SPSS], Madrid: Pearson Educación.

Safari, I., Davaribina, M. and Khoshnevis, I. (2020) 'The Influence of EFL Teachers' Self-Efficacy, Job Satisfaction and Reflective Thinking on their Professional Development: A Structural Equation Modeling', Journal on Efficiency and Responsibility in Education and Science, Vol. 13, No. 1, pp. 27-40. https://doi.org/10.7160/ eriesj.2020.130103

Sánchez Díaz, M. (2012) 'La gestión de competencias informacionales en las universidades: reto para los profesionales de la información', [The management of informational competences in universities: a challenge for information professionals], Vivat Academia, Vol. 15, No. 121, pp. 50-64. https://doi.org/10.15178/va.2012.121.50-64
Solís Valdespino, B. E. (2013) Curso: Desarrollo de Habilidades Informativas en el estudiante universitario, [Course: Development of Informational Skills in the university student], San Luis Potosí: Universidad Autónoma de San Luis Potosí, [Online], Available: http://bibliotecas.uaslp.mx/ autoridades/5ta.conferenciay3ersem/Talleres/Curso\%20DHI Blanca $\% 20$ Solis $2013 /$ Curso $\% 20 \% 20 \mathrm{DHI} \% 20$ Solis.pdf $\quad[1 \overline{8}$ Oct 2020].

UNESCO (2020) Consecuencias negativas del cierre de las escuelas, [Negative consequences of school closings], United Nations Educational, Scientific and Cultural Organization [Online], Available: https://es.unesco.org/covid19/educationresponse/consecuencias [12 May 2020].

Wang, Y., Peng, H., Huang, R., Hou, Y. and Wang, J. (2008) 'Characteristics of distance learners: research on relationships of learning motivation, learning strategy, self-efficacy, attribution and learning results', Open Learning: The Journal of Open, Distance and e-Learning, Vol. 23, No. 1, pp. 17-28. https://doi.org/10.1080/02680510701815277

Wang, G., Cheng, Z., Yue, X. and McAleer, M. (2020) 'Risk Management of COVID-19 by Universities in China', Journal of Risk and Financial Management, Vol. 13, No. 2, pp. 36-41. https://doi.org/10.3390/jrfm13020036

Y1ldızlı, H. (2019) 'Structural Relationships among Teachers' Goal Orientations for Teaching, Self-efficacy, Burnout, and Attitudes towards Teaching', Journal on Efficiency and Responsibility in Education and Science, Vol. 12, No. 4, pp. 111-125. https://doi.org/10.7160/eriesj.2019.120402 